Article

\title{
Bioremediation Capacity of Edaphic Cyanobacteria Nostoc linckia for Chromium in Association with Other Heavy-Metals-Contaminated Soils
}

\author{
Liliana Cepoi ${ }^{1}{ }^{(0)}$, Inga Zinicovscaia ${ }^{2,3, *}{ }^{\mathbb{C}}$, Ana Valuta ${ }^{1}$, Liviu Codreanu ${ }^{1}$, Ludmila Rudi ${ }^{1}{ }^{(\mathbb{O},}$, Tatiana Chiriac ${ }^{1}$, \\ Nikita Yushin ${ }^{2}$, Dmitrii Grozdov ${ }^{2}$ and Alexandra Peshkova ${ }^{2}$ \\ 1 Laboratory of Phycobiotechnology, Institute of Microbiology and Biotechnology, 1, Academiei Str., \\ MD-2028 Chisinau, Moldova; lilianacepoi@yahoo.com (L.C.); annavaluta@yahoo.com (A.V.); \\ co_liv@mail.ru (L.C.); rudiludmila@gmail.com (L.R.); chiriac_tv@yahoo.com (T.C.) \\ 2 Department of Nuclear Physics, Joint Institute for Nuclear Research, 6 Joliot-Curie Str., \\ 1419890 Dubna, Russia; ynik_62@mail.ru (N.Y.); dsgrozdov@rambler.ru (D.G.); \\ peshkova.alexandra92@gmail.com (A.P.) \\ 3 Department of Nuclear Physics, Horia Hulubei National Institute for R\&D in Physics and Nuclear \\ Engineering, 30 Reactorului Str. MG-6, 077125 Magurele, Romania \\ * Correspondence: zinikovskaia@mail.ru; Tel.: +7-4962165609
}

check for updates

Citation: Cepoi, L.; Zinicovscaia, I.; Valuta, A.; Codreanu, L.; Rudi, L.; Chiriac, T.; Yushin, N.; Grozdov, D.; Peshkova, A. Bioremediation Capacity of Edaphic Cyanobacteria Nostoc linckia for Chromium in Association with Other

Heavy-Metals-Contaminated Soils. Environments 2022, 9, 1. https:// doi.org/10.3390/environments9010001

Academic Editor:

Gianniantonio Petruzzelli

Received: 1 December 2021

Accepted: 22 December 2021

Published: 23 December 2021

Publisher's Note: MDPI stays neutral with regard to jurisdictional claims in published maps and institutional affiliations.

Copyright: (C) 2021 by the authors. Licensee MDPI, Basel, Switzerland. This article is an open access article distributed under the terms and conditions of the Creative Commons Attribution (CC BY) license (https:// creativecommons.org/licenses/by/ $4.0 /)$.

\begin{abstract}
Anthropogenic activity is the main factor contributing to soil pollution with various toxic metals, including $\mathrm{Cr}(\mathrm{VI})$, which dictates the need for decontamination. Often, the traditionally used remediation methods (soil removal, stabilization/solidification, physicochemical extraction, and soil washing) are not sufficiently efficient. Among gentle soil remediation, options can be considered. The aim of this study is to assess the ability of Nostoc linckia to remediate soils contaminated with $\mathrm{Cr}(\mathrm{VI})$ in association with other metals. Metal uptake by biomass was assessed using neutron activation analysis, while the components of Nostoc biomass were determined using specific methods. The capacity to accumulate chromium from the contaminated environment $(\mathrm{Cr}$ in association with $\mathrm{Fe}, \mathrm{Ni}$, $\mathrm{Cu}$, and $\mathrm{Zn}$ ) by the Nostoc linckia is kept at a high level for three generations of cyanobacterium, and the capacity to accumulate $\mathrm{Fe}, \mathrm{Ni}, \mathrm{Cu}$, and $\mathrm{Zn}$ is growing over the cultivation cycles. The process of accumulation of heavy metals is associated with significant changes in the biochemical composition of Nostoc biomass. Due to the high bioaccumulation capacity and the specific growth mode with the formation of crusts on the soil surface, the edaphic cyanobacteria Nostoc linckia is an important candidate for the bioremediation of soil contaminated with chromium in association with other metals.
\end{abstract}

Keywords: Nostoc linckia; bioaccumulation; chromium; repeated contamination; neutron activation analysis

\section{Introduction}

The high demand for metals in the fast-growing industrial sector around the world has led to their extensive extraction and production in huge quantities. This phenomenon in turn has exacerbated the problem of severe soil pollution with heavy metals in recent decades.

Soil pollution with various toxic metals, including chromium, occurs in two main ways-natural and anthropogenic. Chromium is present in water, soil, and air in several oxidation states, but the most stable and common forms are $\mathrm{Cr}(\mathrm{III})$ and $\mathrm{Cr}(\mathrm{VI})$. In water, this element occurs naturally as a result of microorganisms' interactions with mafic and ultramafic igneous rocks together with geogenic processes [1]. The total concentration of chromium in water depends on the physicochemical properties of the water basin. Continental dust flux and volcanic ash are natural sources of chromium in the atmosphere. The content of chromium in soil is dependent on soil-forming material, chromium deposition, and the contribution of wastewater containing chromium as well as soil processing technologies [2]. 
However, chromium contamination is considered a serious environmental problem mainly due to industrial processes. Chromium compounds are widely applied in machinery, textile industry, steel production, batteries and dyes production, and leather processing. The combustion of oil and coal also contribute to the atmospheric burden of chromium $[1,3]$.

Sanitary norms regarding the level of chromium in the environment are established in accordance with national standards and geological conditions (the presence of chromium ores). In European countries (EU), the maximum level of total chromium in wastewater lies between 0.3 and $4.0 \mathrm{mg} / \mathrm{L}$, and that of $\mathrm{Cr}(\mathrm{VI})$ should not exceed $0.5 \mathrm{mg} / \mathrm{L}$ [1]. In drinking water, the maximum permissible level of $\mathrm{Cr}(\mathrm{VI})$ is $0.05 \mathrm{mg} / \mathrm{L}$.

The prevalence of one of the two valence states in the soil, $\mathrm{Cr}$ (III) or $\mathrm{Cr}$ (VI), depends on soil $\mathrm{pH}$ values, redox potential, and presence of natural reducing agents. It was shown that the dominant $\mathrm{Cr}(\mathrm{VI})$ species are anionic forms $\mathrm{CrO}_{4}{ }^{2-}, \mathrm{HCrO}_{4}{ }^{-}$, and $\mathrm{Cr}_{2} \mathrm{O}_{7}{ }^{2-} . \mathrm{Cr}(\mathrm{VI})$ compounds are characterized by very high solubility and mobility, which makes them inaccessible to natural soil colloids, which could neutralize them, as is the case with $\mathrm{Cr}$ (III). As a result, $\mathrm{Cr}(\mathrm{VI})$ compounds are extremely toxic to living organisms $[2,4]$.

Being highly mobile, $\mathrm{Cr}(\mathrm{VI})$ is taken up by plants through carriers of essential ions, such as sulfate transporters. The accumulation of chromium in plants leads to a decrease in germination, growth retardation, inhibition of enzymatic activity in tissues, etc. [5]. Consequently, chromium uptake into the plants is transferred to the upper links of the food chain, including humans.

When $\mathrm{Cr}(\mathrm{VI})$ enters cells it is exposed to cellular reducers, such as glutathione or ascorbic acid. In the process of $\mathrm{Cr}(\mathrm{VI})$ reduction, intermediate forms $\mathrm{Cr}(\mathrm{V})$ and $\mathrm{Cr}(\mathrm{IV})$ are obtained, which are highly reactive and cause the activation of molecular oxygen with the generation of various reactive oxygen species, including hydroxyl radical. This, in turn, reacts with biomolecules, including nucleic acids, inducing various mutations [3]. This is considered to be the underlying mechanism of the toxicity and carcinogenic effects of hexavalent chromium.

Thus, in order to avoid the risks arising from the presence of $\mathrm{Cr}(\mathrm{VI})$ in the soil, chromium undergoes a variety of remediation procedures. In this regard, there are two main approaches - traditional soil remediation by physicochemical methods and bioremediation. The remediation using traditional methods includes soil flushing, landfilling, solidification-stabilization, and chemical reduction of $\mathrm{Cr}(\mathrm{VI})$. It is recognized that these methods are hard to achieve, economically disadvantageous, and in most cases cause secondary environmental pollution.

Bioremediation can be performed using a variety of living organisms or biomass derivatives. In most cases, phytoremediation exploits the ability of some plant species or some plant species mixtures adjusted to the habitat conditions to uptake and metabolize heavy metals, in this case chromium [6,7]. The disadvantage of this approach lies in the long duration (equivalent to a period of vegetation) of the process. In this respect, microorganisms with a short generation time are more preferable, since they are able to accumulate a large amount of $\mathrm{Cr}(\mathrm{VI})$, which subsequently undergo biotransformation/reduction; thus, achieving soil detoxification [8-11].

On the other hand, different groups of soil microorganisms possess different degrees of resistance to heavy metals, including chromium, and different abilities to reduce their toxicity. Edaphic cyanobacteria are the least studied in this respect. At the same time, it is known that they can produce a large number of extracellular polymers, such as polysaccharides, glycoproteins, lipopolysaccharides, which have multiple anionic functional groups that can form coordination bonds with $\mathrm{Cr}(\mathrm{VI})$ [12].

In this respect, Nostoc linckia is a promising edaphic cyanobacterium. It has been shown that it can be used for chromium biosorption from wastewater. In addition to chromium, Nostoc biomass accumulated the amount of iron and zinc that exceeds their concentrations in the control biomass samples by six and eight times, respectively [13].

Biosorption of metals, including $\mathrm{Cr}(\mathrm{VI})$ using dead biomass or biomass derivatives is mainly applicable for aquatic environments and is not considered as a practical method 
for soil remediation, as further steps are required to complete the metal removal process. Instead, the bioaccumulation process, which is an active process, uses only living organisms that not only concentrate the metal in cells, but also undergo it to subsequent reduction/biotransformation, converting the pollutant to less toxic forms.

The bioaccumulation of chromium needs to be studied together with the accumulation of other elements present in the polluted environment since the efficiency of metal removal from mono- and multi-metallic systems is usually different. For instance, cyanobacterium spirulina is more effective in removing $\mathrm{Cr}(\mathrm{VI})$ from multi-metallic systems than from monometallic ones [14].

Moreover, pollution of the environment, including soil, has a discontinuous character, the contact of living microorganisms with pollutants occurs repeatedly, affecting different generations. It is interesting to note microorganisms' ability to adapt to repeated exposure to contaminants, as well as to monitor the long-term effects of this exposure.

Based on the above, this study aimed to assess the ability of cyanobacterium Nostoc linckia to bioaccumulate chromium along with other metal ions from multi-metallic systems under conditions of repeated pollution and changes in the quality of biomass obtained under these conditions.

\section{Materials and Methods}

The following salts, $\mathrm{K}_{2} \mathrm{CrO}_{7}, \mathrm{CuSO}_{4}, \mathrm{FeCl}_{3} \cdot 6 \mathrm{H}_{2} \mathrm{O}, \mathrm{Ni}\left(\mathrm{NO}_{3}\right) \cdot 6 \mathrm{H}_{2} \mathrm{O}$, and $\mathrm{ZnCl}_{2}$ (purity $\geq 97 \%$ ) (Sigma-Aldrich, Darmstadt, Germany) were used for multi-metal batch systems preparation. The chemical composition of multi-metal systems is presented in Table 1.

Table 1. Multi-metal systems' chemical composition.

\begin{tabular}{lccccc}
\hline \multirow{2}{*}{ Systems Designation } & \multicolumn{5}{c}{ Metal Concentration, mg/L } \\
\cline { 2 - 5 } & $\mathbf{C r}$ & Fe & Ni & Zn & Cu \\
\hline $\mathrm{Cr} / \mathrm{Fe}$ & 2.5 & 2.0 & - & - & - \\
$\mathrm{Cr} / \mathrm{Fe} / \mathrm{Ni}$ & 2.5 & 2.0 & 0.5 & - & - \\
$\mathrm{Cr} / \mathrm{Fe} / \mathrm{Ni} / \mathrm{Zn}$ & 2.5 & 2.0 & 0.5 & 0.5 & - \\
$\mathrm{Cr} / \mathrm{Fe} / \mathrm{Ni} / \mathrm{Zn} / \mathrm{Cu}$ & 2.5 & 2.0 & 0.5 & 0.5 & 0.5 \\
\hline
\end{tabular}

The object of the study was cyanobacterial strain Nostoc linckia (Roth) Born et Flah CNM-CB-03, deposited in the National Collection of Nonpathogenic Microorganisms of the Republic of Moldova.

For obtaining inoculum for the first cycle, cyanobacterium was grown in a mineral medium with the following composition: macroelements in $\mathrm{g} / \mathrm{L}-\mathrm{KNO}_{3}-0.5, \mathrm{~K}_{2} \mathrm{HPO}_{4}-0.45$, $\mathrm{NaHCO}_{3}-0.05, \mathrm{MgSO}_{4} \cdot 7 \mathrm{H}_{2} \mathrm{O}-0.1, \mathrm{CaCl}_{2}-0.11$, and microelements in $\mathrm{mg} / \mathrm{L}-\mathrm{ZnSO}_{4} \cdot 7 \mathrm{H}_{2} \mathrm{O}-0.05$, $\mathrm{MnSO}_{4}-2.0, \mathrm{H}_{3} \mathrm{BO}_{3}-0.85,\left(\mathrm{NH}_{4}\right)_{6} \mathrm{Mo}_{7} \mathrm{O}_{24} \cdot 4 \mathrm{H}_{2} \mathrm{O}-2.25, \mathrm{FeSO}_{4} \cdot 7 \mathrm{H}_{2} \mathrm{O}-4.0, \mathrm{Co}\left(\mathrm{NO}_{3}\right)_{2} \cdot \mathrm{H}_{2} \mathrm{O}-0.009$, and EDTA-4.75. For experiments, the same medium, but without microelements, was used.

Cultivation was carried out in Erlenmeyer flasks of $1000 \mathrm{~mL}$ with a working volume of $700 \mathrm{~mL}$. The following parameters were used: $\mathrm{pH}$ of the medium 6.8-7.2, temperature $25-27^{\circ} \mathrm{C}$, light intensity of 37-55 $\mu \mathrm{mol}$ photons $\mathrm{m}^{-2} \mathrm{~s}^{-1}$, continuous illumination, and slow periodic shaking. The amount of inoculum was $0.4 \mathrm{~g} / \mathrm{L}$.

Metals were added to the culture medium on the sixth day (exponential growth phase) of biomass growth. The cultivation cycle lasted 12 days, the $\mathrm{pH}$ of the mixture during one cultivation cycle was in the range of 6.8-7.2. At the end of the cultivation cycle, $100 \mathrm{~mL}$ of biomass suspension was used for biochemical tests; $300 \mathrm{~mL}$ was used for neutron activation analysis (NAA), and $300 \mathrm{~mL}$ was used for subculturing. Each of the 3 portions of biomass was centrifuged to separate the growth medium, then biomass was washed with doubledistilled water and used for further experiments. The procedure was repeated two more times. At the end of the bioaccumulation experiments, the biomass was separated from the culture medium by centrifugation. The amount of biomass was determined based on the calibration curve. For biochemical analysis, the samples were standardized to a 
concentration of $10 \mathrm{mg} / \mathrm{mL}$ with distilled water and subjected to a repeated freezingthawing procedure. For NAA analysis, the biomass was dried at $100 \pm 2{ }^{\circ} \mathrm{C}$. The same procedure was performed with control biomass but without the addition of metal ions.

Obtaining extracts. Water and alcohol extracts were obtained by extraction in distilled water and, respectively, in alcohol of $96 \%$ in the ratio of $10 \mathrm{mg}$ biomass per $1 \mathrm{~mL}$ of extractant. The extraction was performed by biomass stirring at room temperature for $24 \mathrm{~h}$.

\subsection{Neutron Activation Analysis}

Metal accumulation by Nostoc linckia biomass was assessed by neutron activation analysis (NAA) at the REGATA facility of the IBR-2 reactor (Dubna, Russia) [15]. To determine $\mathrm{Cr}, \mathrm{Fe}, \mathrm{Ni}$, and $\mathrm{Zn}$ content samples were irradiated for 3 days at a neutron flux of $3.31 \times 10^{11} \mathrm{n} \mathrm{cm}^{-2} \mathrm{~s}^{-1}$, re-packed, and measured twice using HP germanium detectors after 4 and 20 days of decay, respectively. The chromium content in the samples was determined by a $\gamma$-line with the energy of $312.0 \mathrm{keV}$ of isotope ${ }^{51} \mathrm{Cr}$, iron by a $\gamma$-line with the energy of $1099.25 \mathrm{keV}$ of isotope ${ }^{59} \mathrm{Fe}$, nickel by a $\gamma$-line with the energy of $810.57 \mathrm{keV}$ of isotope ${ }^{58} \mathrm{Co}$, and zinc by a $\gamma$-line with the energy of $1115.54 \mathrm{keV}$ of isotope ${ }^{65} \mathrm{Zn}$. To determine copper content, samples were irradiated for 3 min at a neutron flux of $1.6 \times 10^{12} \mathrm{n} \mathrm{cm}^{-2} \mathrm{~s}^{-1}$ and measured directly after irradiation. Copper content in the samples was determined by a $\gamma$-line with the energy of $1039.2 \mathrm{keV}$ of isotope ${ }^{66} \mathrm{Cu}$. The NAA data processing and calculation of element concentrations were performed using the FLNP JINR software [16].

\subsection{Biochemical Analysis}

Protein content in the biomass was determined spectrophotometrically by the Lowry method [17]. Protein extraction was carried out with $0.1 \mathrm{~N} \mathrm{NaOH}$, for which $0.9 \mathrm{~mL}$ of $0.1 \mathrm{~N} \mathrm{NaOH}$ was added to $10 \mathrm{mg}$ biomass for $30 \mathrm{~min}$. Then, to $0.2 \mathrm{~mL}$ alkaline protein extract hydrolysate was added $2.0 \mathrm{~mL}$ reagent $(49 \mathrm{~mL}$ of $2 \%$ sodium carbonate in $0.1 \mathrm{~N}$ sodium hydroxide and $1.0 \mathrm{~mL}$ of $0.5 \%$ copper sulfate in $1.0 \%$ sodium citrate). After $10 \mathrm{~min}$ of incubation at room temperature, $0.2 \mathrm{~mL}$ of Folin-Ciocalteu reagent (F9252 (SigmaAldrich, Darmstadt, Germany) suitable for determination of total protein by Lowry method) diluted with distilled water for four times was added to the reaction mixture. At the end of the incubation time (30 $\mathrm{min}$ ) the absorbance was measured at $750 \mathrm{~nm}$. Protein content was calculated using a calibration curve for bovine serum albumin.

Carbohydrate content was determined by a spectrophotometric method using an anthrone reagent. For this, $2.5 \mathrm{~mL}$ of $0.5 \%$ anthrone solution in $66 \%$ sulfuric acid was carefully added to $0.25 \mathrm{~mL}$ of analyzed sample. The samples were incubated in a boiling water bath for $30 \mathrm{~min}$, after which they were cooled under tap water and exposed in the dark for $30 \mathrm{~min}$. The blue-green solution shows an absorption maximum at $620 \mathrm{~nm}$. The carbohydrate content was calculated using a calibration curve for glucose [18].

Quantitative determination of lipids was carried out spectrophotometrically using the phospho-vanillin reagent. For this purpose the lipidic extract was prepared by mixing $10 \mathrm{mg}$ of biomass with $1 \mathrm{~mL}$ of chloroform and ethanol in the ratio de 9:1 $(v / v)$. Extraction was performed at room temperature by continuous stirring for $120 \mathrm{~min}$. The chloroform extract was separated from biomass. After removing the solvent by evaporation, $1 \mathrm{~mL}$ of concentrated sulfuric acid was added to the lipid extract. The samples were placed in a water bath for $10 \mathrm{~min}$. Then, $2.9 \mathrm{~mL}$ of phospho-vanillin reagent was added to $0.1 \mathrm{~mL}$ of lipid hydrolysate. After $30 \mathrm{~min}$, the absorbance was measured at the wavelength of $520 \mathrm{~nm}$. The lipid content was calculated using a calibration curve based on oleic acid [19].

Total phenolic content was determined using the Folin-Ciocalteu reagent. An amount of $0.3 \mathrm{~mL}$ of biomass extract was moxed with $1.5 \mathrm{~mL}$ of Folin-Ciocalteu reagent diluted 10 times and $1.2 \mathrm{~mL}$ of $7.5 \%$ sodium carbonate. The mixture was stirred and incubated at $50{ }^{\circ} \mathrm{C}$ for $30 \mathrm{~min}$. After cooling the samples, the absorbance was measured at $760 \mathrm{~nm}$. The total phenolic content was calculated from the calibration curve, and the results were expressed as mg of gallic acid equivalent per g dry weight [20]. 
Phycobiliprotein content was calculated on the basis of the formula of Siegelman and Kycia [21]. The method is based on the determination of the absorbance of water extract, obtained as a result of the procedure of repeated freezing-thawing of standardized Nostoc biomass. The absorbance of the extract was measured at wavelengths 565, 620, and $650 \mathrm{~nm}$, which represent maximum absorption peaks of phycoerythrin (PE), phycocyanin (PC), and allophycocyanin (APC), respectively.

Determination of the products of oxidative degradation of lipids in biomass was carried out by calculating the content of malondialdehyde (MDA) based on the reactive substances of thiobarbituric acid (TBA). An amount of $0.1 \mathrm{~mL}$ of biomass $(10 \mathrm{mg} / \mathrm{mL})$ was mixed with $3.0 \mathrm{~mL}$ of $0.76 \%$ solution of TBA in a $20 \%$ solution of trichloroacetic acid. The reaction mixture was incubated at $95^{\circ} \mathrm{C}$ for $20 \mathrm{~min}$. After cooling the samples, the optical density was determined at wavelengths of $532 \mathrm{~nm}$ and $600 \mathrm{~nm}$. The amount of MDA in the samples was calculated using the molar extinction coefficient for the MDA-TBA complex [22].

Quantitative determination of chlorophyll and $\beta$-carotene content was established using $10 \mathrm{mg}$ of Nostoc biomass mixed with $1.0 \mathrm{~mL}$ of $96 \%$ ethanol. Pigment extraction was performed by continuous stirring at room temperature for $120 \mathrm{~min}$. The ethanolic extract was separated from biomass by centrifugation. The chlorophyll content was determined based on the absorbance at $665 \mathrm{~nm}$ and the extinction coefficient $0.8 \times 10^{5} \mathrm{M}^{-1} \cdot \mathrm{cm}^{-1}$, and $\beta$-carotene was determined based on the absorbance at $450 \mathrm{~nm}$ and the extinction coefficient $1.5 \times 10^{5} \mathrm{M}^{-1} \cdot \mathrm{cm}^{-1}[16]$.

Antioxidant activity was established using ABTS (2,2'-azino-bis(3-ethylbenzothiazoline6-sulfonic acid)) assay [23]. The radical cation $\mathrm{ABTS}^{+}$is produced from the reaction between ABTS solution and potassium persulfate. For this purpose, a $7 \mathrm{mM}$ ABTS stock solution was prepared in deionized water, to which $2.45 \mathrm{mM}$ potassium persulfate was added in a ratio of $1: 1 \mathrm{v} / \mathrm{v}$. The oxidation of ABTS occurred in the dark at room temperature for at least $12-16 \mathrm{~h}$. The working solution was prepared from the ABTS stock solution and had an absorbance of $0.700 \pm 0.020$ at $734 \mathrm{~nm}$. The reaction mixture consisted of $0.3 \mathrm{~mL}$ of biomass extract and $2.7 \mathrm{~mL}$ of ABTS solution. The absorbance of the samples was measured after $6 \mathrm{~min}$. The \% of inhibition relative to the absorbance of the ABTS reagent was calculated.

\subsection{Statistical Analysis}

All experiments were performed in triplicate. The results in all histograms are presented as mean values \pm standard deviations. Differences between the values were estimated by Student's $t$-tests.

\section{Results}

\subsection{The Biomass of Nostoc in Three Cultivation Cycles}

Biomass accumulation is one of the main parameters which allow assessment of the level of pollutants toxicity for microorganisms. For this reason, the amount of Nostoc biomass accumulated during each of the three vital cycles was monitored (Figure 1). The first vital cycle in all studied polymetallic systems was characterized by a high level of biomass productivity. In the $\mathrm{Cr} / \mathrm{Fe}, \mathrm{Cr} / \mathrm{Fe} / \mathrm{Ni}$, and $\mathrm{Cr} / \mathrm{Fe} / \mathrm{Ni} / \mathrm{Zn}$ systems, the amount of biomass did not differ significantly from the control. In the $\mathrm{Cr} / \mathrm{Fe} / \mathrm{Ni} / \mathrm{Zn} / \mathrm{Cu}$ system, the amount of Nostoc biomass accumulated at the end of the first cycle was $16.5 \%$ lower compared with the control sample $(p=0.00138)$. In the second cycle of Nostoc cultivation, the amount of biomass was rather uniform but significantly lower than in the control (on average by $32-35 \%, p<0.001$ ). The Nostoc culture was exposed to metals during the first cultivation cycle; in the second cycle it showed a more pronounced sensitivity, expressed in a decrease in productivity by about one third compared with the normal level, regardless of the composition of the multi-metallic system. The third cultivation cycle for $\mathrm{Cr} / \mathrm{Fe}$ and $\mathrm{Cr} / \mathrm{Fe} / \mathrm{Ni}$ systems ended with the same biomass level as in the second one. In the other two systems, $\mathrm{Cr} / \mathrm{Fe} / \mathrm{Ni} / \mathrm{Zn}$ and $\mathrm{Cr} / \mathrm{Fe} / \mathrm{Ni} / \mathrm{Zn} / \mathrm{Cu}$, the amount of biomass continued to decrease. For these two systems, the biomass productivity at the end of the 
third cycle decreased compared with the second cycle by $18 \%$ and $20 \%$, respectively. In these two systems, biomass decreased about two times at the end of the third cultivation cycle compared with the control.

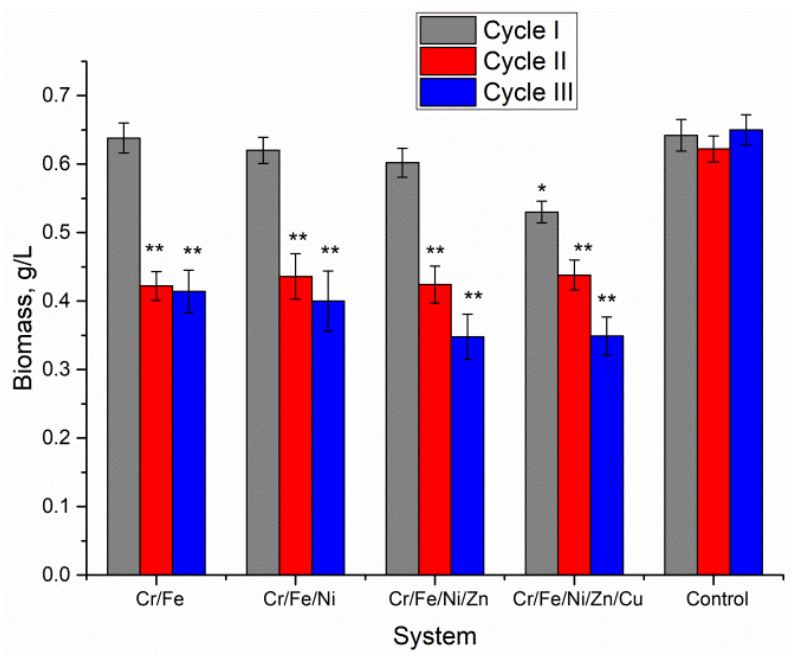

Figure 1. Biomass of Nostoc linckia obtained during three cycles of cultivation on media containing metal ions $\left({ }^{*} p<0.005 ;{ }^{* *} p<0.001\right)$.

\subsection{Bioaccumulation of Chromium and Other Metals in the Biomass}

The bioaccumulation of chromium in Nostoc biomass in all systems during all cycles was at a quite high level ranging from 1190 to $3300 \mu \mathrm{g} / \mathrm{g}$ dry biomass, taking into account that the content of chromium detected in the control biomass was $3.4 \mu \mathrm{g} / \mathrm{g}$ (Figure 2). For all four systems, the amount of chromium taken up by Nostoc biomass in the second cultivation cycle was $11-26 \%$ higher than in the first cycle. In the third cycle, the systems differed in this respect. Thus, in three systems, $\mathrm{Cr} / \mathrm{Fe}, \mathrm{Cr} / \mathrm{Fe} / \mathrm{Ni}$, and $\mathrm{Cr} / \mathrm{Fe} / \mathrm{Ni} / \mathrm{Zn}$, chromium accumulation capacity was reduced in comparison with the second cycle and was comparable with that in the first cycle, while in the $\mathrm{Cr} / \mathrm{Fe} / \mathrm{Ni} / \mathrm{Zn} / \mathrm{Cu}$ system, chromium uptake did not differ from the second cycle. Among all analyzed systems, the greatest uptake of chromium was noticed in the $\mathrm{Cr} / \mathrm{Fe} / \mathrm{Ni} / \mathrm{Zn}$ system, its accumulation was $29-178 \%$ higher in comparison with other analyzed variants (systems and cycles). The maximum level of chromium accumulation in Nostoc biomass was $3300 \mu \mathrm{g} / \mathrm{g}$, and it was reached at the end of the second cultivation cycle in the $\mathrm{Cr} / \mathrm{Fe} / \mathrm{Ni} / \mathrm{Zn}$ system. Chromium concentration in this variant was almost 1000 times higher than in the control biomass and indicates the ability of excessive accumulation of $\mathrm{Cr}(\mathrm{VI})$ by Nostoc biomass.

Iron was the second element present in all analyzed systems. The amount of iron accumulated in Nostoc biomass grown in multi-metallic systems was 3060-7100 $\mu \mathrm{g} / \mathrm{g}$, which was significantly higher compared with control, where its level reached the value of $820 \mu \mathrm{g} / \mathrm{g}$ (Figure 2). Iron uptake increased from one cultivation cycle to another in all systems, and within each cycle this parameter was rather uniform. Thus, in the first cycle of cultivation, iron uptake in different systems ranged from 3060-3340 $\mu \mathrm{g} / \mathrm{g}$ without any statistically significant differences between the variants of the system. The second cycle of Nostoc growth ended with an accumulation of iron by $49-89 \%$ higher than in the first cycle of cultivation $(p<0.001)$. In the third cycle, iron uptake increased in three of the analyzed systems, $\mathrm{Cr} / \mathrm{Fe} / \mathrm{Ni}, \mathrm{Cr} / \mathrm{Fe} / \mathrm{Ni} / \mathrm{Zn}$, and $\mathrm{Cr} / \mathrm{Fe} / \mathrm{Ni} / \mathrm{Zn} / \mathrm{Cu}$; the accumulated amount was $20.3-40.5 \%$ higher than in the second cycle $(p<0.005)$. No significant differences were found in the $\mathrm{Cr} / \mathrm{Fe}$ system between iron uptake in the second and third cycles. The amount of iron taken up by Nostoc biomass grown on multi-metallic systems was 3.7-8.6 times higher than in control biomass, while the ability to uptake this metal was less pronounced compared with that of chromium. 

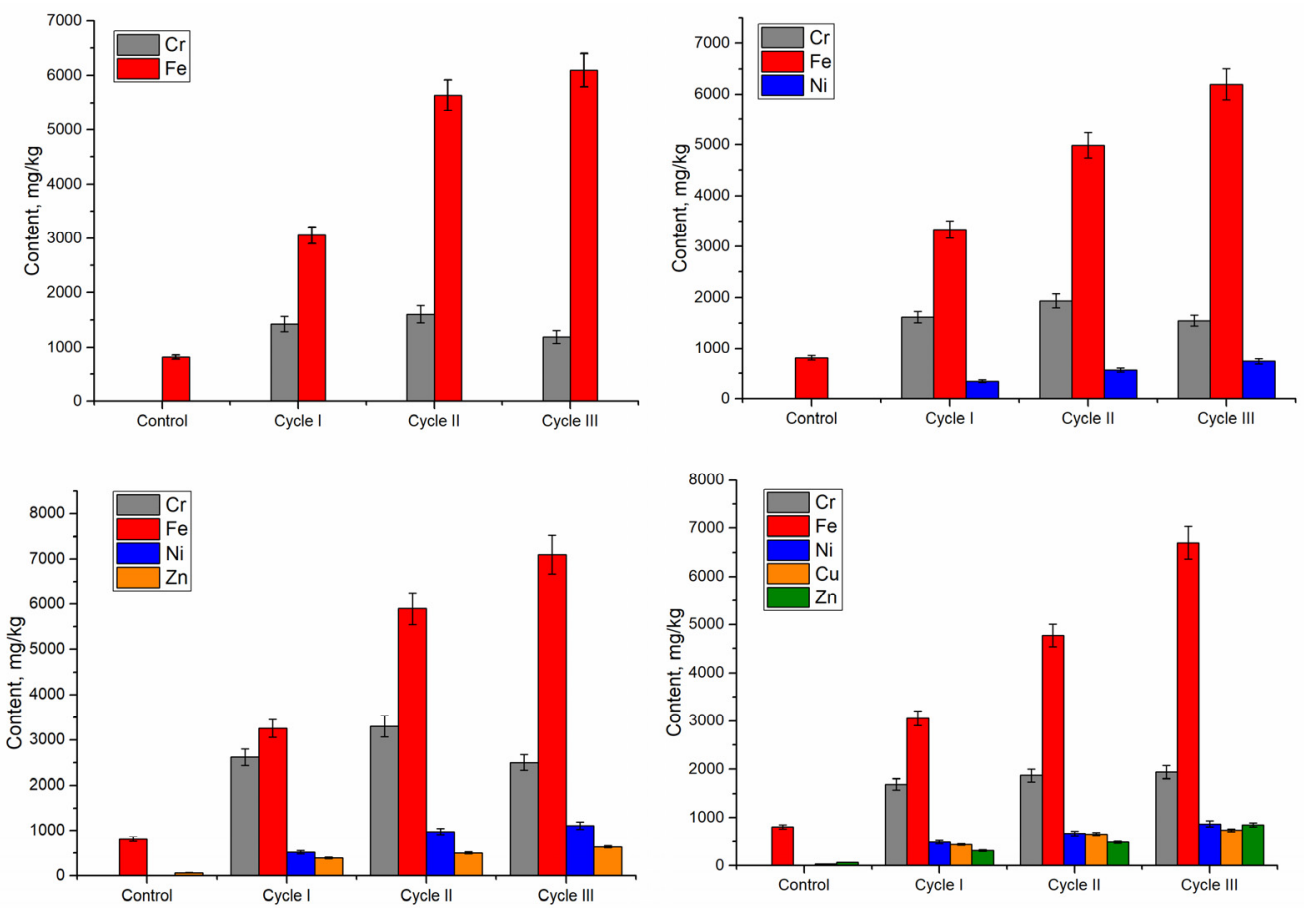

Figure 2. Bioaccumulation of chromium and other metals by Nostoc linckia biomass during 3 life cycles on media containing multi-metallic systems.

Nickel was not detected in control Nostoc biomass, and in biomass grown on three multi-metallic systems containing this element it was 348-1110 $\mu \mathrm{g} / \mathrm{g}$ (Figure 2). As in the case of iron, nickel uptake increased over the cycles. Thus, compared with the first growth cycle, nickel uptake in the second cycle was 37-88\% higher $(p<0.001)$, and in the third cycle it was $13-30 \%$ higher than in the second cycle. As for chromium and iron, the $\mathrm{Cr} / \mathrm{Fe} / \mathrm{Ni} / \mathrm{Zn}$ system turned out to be the most efficient in terms of Ni uptake, where the maximum level of Ni accumulation in Nostoc biomass reached $980 \mu \mathrm{g} / \mathrm{g}$ in the second cultivation cycle and $1110 \mu \mathrm{g} / \mathrm{g}$ in the third cycle, while the difference between them was statistically insignificant.

Zinc was present in two analyzed systems, and its amount taken up by Nostoc biomass was 312-850 $\mu \mathrm{g} / \mathrm{g}$ (Figure 2). Zinc uptake also increased in biomass over the cycles. Thus, in comparison with the first cycle for $\mathrm{Cr} / \mathrm{Fe} / \mathrm{Ni} / \mathrm{Zn}$ and $\mathrm{Cr} / \mathrm{Fe} / \mathrm{Ni} / \mathrm{Zn} / \mathrm{Cu}$ systems, in the second cycle, zinc uptake increased by $28 \%$ and $55 \%$, respectively, and in the third-by $27 \%$ and $75 \%$, respectively, compared with the second cycle. Taking into account that the control biomass contained $69 \pm 2.9 \mu \mathrm{g} / \mathrm{g}$ of zinc, Nostoc biomass after three cultivation cycles on multi-metallic zinc-containing systems accumulated 9-12 times more zinc in comparison with control.

The amount of copper in the control biomass was $32 \pm 0.38 \mu \mathrm{g} / \mathrm{g}$, and in biomass obtained on a multi-metallic system containing copper-439-740 $\mu \mathrm{g} / \mathrm{g}$, which was 13.7-23.1 times higher than in control (Figure 2). In the first cycle of cultivation, copper uptake by Nostoc biomass was $439 \mu \mathrm{g} / \mathrm{g}$, and in the second cycle metal uptake increased by $50.3 \%$ compared with the first cycle. There was no statistical difference between copper uptake in second and third cycles.

\subsection{The Biochemical Composition of Nostoc Biomass}

The biochemical composition of Nostoc biomass undergoes various changes depending on the analyzed system and the cultivation cycle. The amount of proteins decreased after the first cycle of cultivation in all four systems (Figure 3). In addition, if in the $\mathrm{Cr} / \mathrm{Fe}$, $\mathrm{Cr} / \mathrm{Fe} / \mathrm{Ni}$, and $\mathrm{Cr} / \mathrm{Fe} / \mathrm{Ni} / \mathrm{Zn}$ systems this decrease was moderate, up to $12 \%(p<0.005)$, then in the $\mathrm{Cr} / \mathrm{Fe} / \mathrm{Ni} / \mathrm{Zn} / \mathrm{Cu}$ system the reduction in the amount of proteins was by 
$29 \%$ compared with control. In the second cycle of cultivation, protein content in Nostoc biomass was at the level recorded in the first cycle, without significant differences. Instead, differences between the systems were observed in the third cultivation cycle, when two opposite situations were observed: in the $\mathrm{Cr} / \mathrm{Fe}$ and $\mathrm{Cr} / \mathrm{Fe} / \mathrm{Ni} / \mathrm{Zn} / \mathrm{Cu}$ systems the protein content decreased by $27 \%$ and $44 \%$, respectively, compared with control, while in the $\mathrm{Cr} / \mathrm{Fe} / \mathrm{Ni}$ and $\mathrm{Cr} / \mathrm{Fe} / \mathrm{Ni} / \mathrm{Zn}$ systems this parameter attained the control level (in the $\mathrm{Cr} / \mathrm{Fe} / \mathrm{Ni}$ system), or increased by $18 \%$ (in the $\mathrm{Cr} / \mathrm{Fe} / \mathrm{Ni} / \mathrm{Zn}$ system) in respect to the control $(p<0.005)$. It should be noted that the most serious changes in protein content occurred in the $\mathrm{Cr} / \mathrm{Fe} / \mathrm{Ni} / \mathrm{Zn} / \mathrm{Cu}$ system, where the biomass in all three cultivation cycles had a consistently low protein level (by $29-44 \%$ compared with the control).
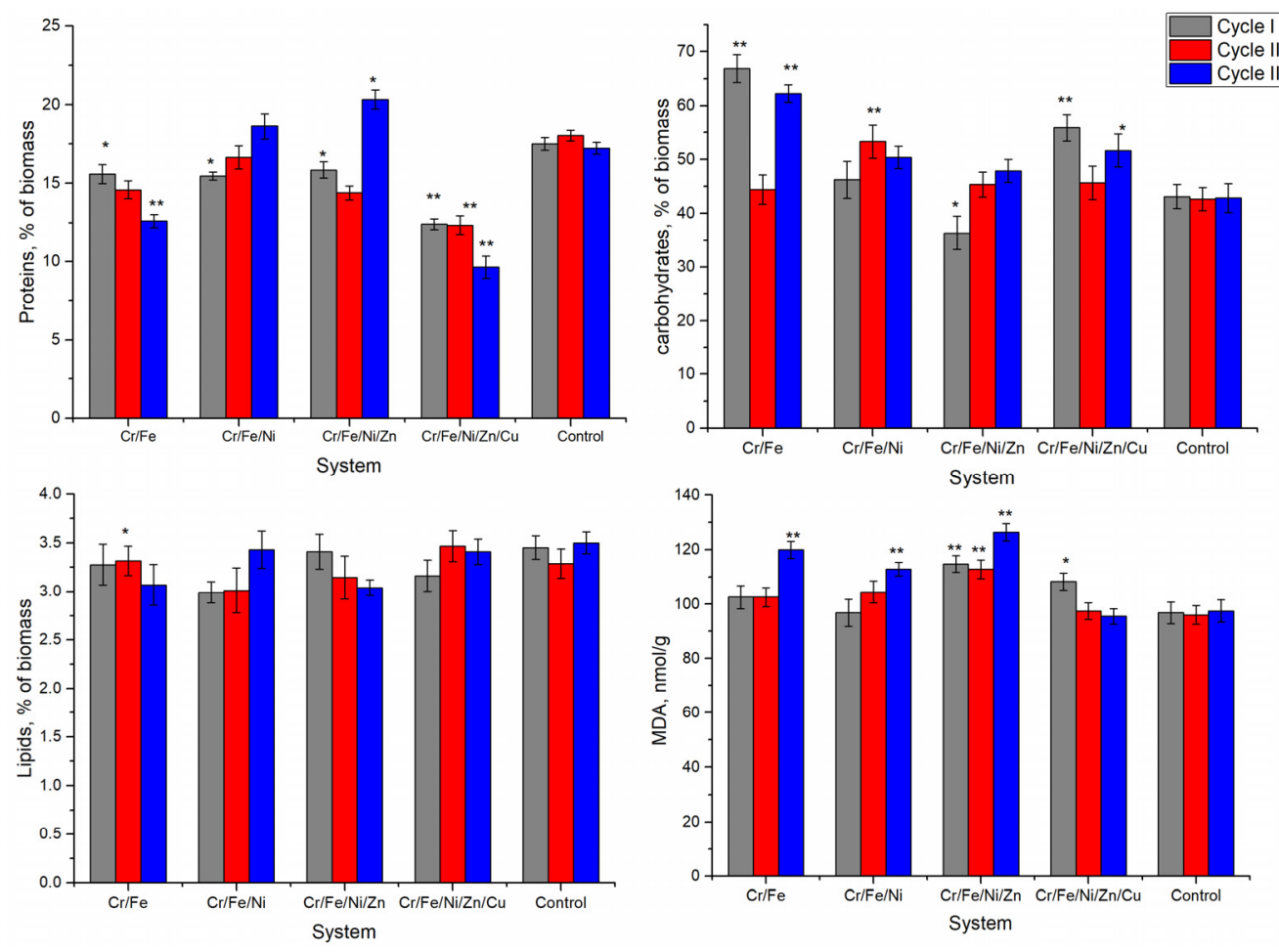

Figure 3. Biochemical composition (total proteins, carbohydrates, lipids, and malondialdehyde) of Nostoc linckia biomass during three cycles of cultivation containing multi-metallic systems. $\left({ }^{*} p<0.005\right.$; ** $p<0.001)$.

A decrease in the amount of carbohydrates in Nostoc biomass by $16 \%(p<0.005)$ was recorded only in the first cultivation cycle in the $\mathrm{Cr} / \mathrm{Fe} / \mathrm{Ni} / \mathrm{Zn}$ system (Figure 3). In other cases, the amount of carbohydrates was at the level of control or exceeded it by up to $55 \%$. In the $\mathrm{Cr} / \mathrm{Fe}$ system, during first and third cycles, the highest amount of carbohydrates was accumulated in Nostoc biomass, reaching $66 \%$ of the dry biomass. In the $\mathrm{Cr} / \mathrm{Fe} / \mathrm{Ni} / \mathrm{Zn} / \mathrm{Cu}$ system during cycles I and III, a significant amount of carbohydrates was synthesized, which exceeded the level of the control by $29.5 \%$ and $20.4 \%$, respectively.

The amount of lipids practically did not change upon contact with media containing heavy metals, remaining at the level of 3.0-3.5\% of dry biomass (Figure 3). Malondialdehyde, one of the end products of oxidative lipid degradation, was found at an adequate level in Nostoc biomass in the range from 95.5 to $126.4 \mathrm{nmol} / \mathrm{g}$ biomass (Figure 3). In all cultivation cycles, values significantly exceeding the content in control biomass were recorded in the $\mathrm{Cr} / \mathrm{Fe} / \mathrm{Ni} / \mathrm{Zn}$ system. The level of malondialdehyde in the third cycle in the $\mathrm{Cr} / \mathrm{Fe}, \mathrm{Cr} / \mathrm{Fe} / \mathrm{Ni}$, and $\mathrm{Cr} / \mathrm{Fe} / \mathrm{Ni} / \mathrm{Zn}$ systems was $15.8-29.7 \%$ higher than in the control sample.

Pigments are cellular components, which usually respond quickly to the action of stress factors. Nostoc biomass contains three groups of pigments: phycobiliproteins, chlorophyll, 
and carotenoid pigments. The change in their content in biomass in multi-metallic systems is shown in Figure 4.
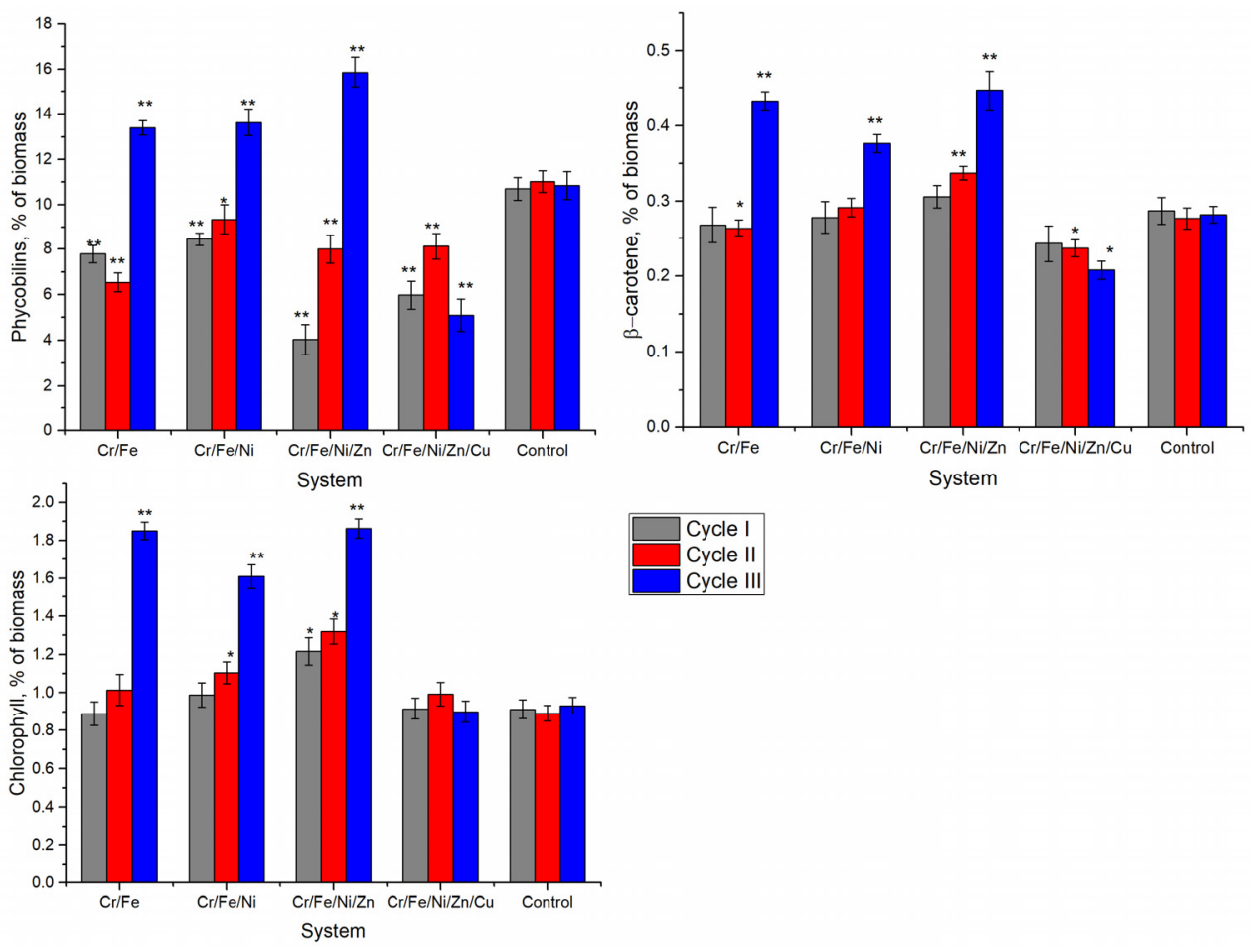

Figure 4. Pigment content (total phycobiliproteins, chlorophyll $\alpha$, and $\beta$-carotene) in Nostoc linckia biomass during three cycles of cultivation media containing multi-metallic systems. $\left({ }^{*} p<0.005\right.$; ** $p<0.001)$.

The most pronounced change in the content of phycobiliproteins occurred during the first two cycles of Nostoc cultivation in multi-metallic systems. At the end of these two cycles, in all studied systems, the content of total phycobiliproteins was $15.2-62.4 \%$ lower than in the control. In the third cultivation cycle, two different situations were observed. Thus, in multi-metallic systems, $\mathrm{Cr} / \mathrm{Fe}, \mathrm{Cr} / \mathrm{Fe} / \mathrm{Ni}$, and $\mathrm{Cr} / \mathrm{Fe} / \mathrm{Ni} / \mathrm{Zn}$, the amount of phycobiliproteins increased significantly, exceeding the characteristic control level by 23.7-46.3\%. On the contrary, in the $\mathrm{Cr} / \mathrm{Fe} / \mathrm{Ni} / \mathrm{Zn} / \mathrm{Cu}$ system, it decreased both in comparison with the control as well as cycles I and II. Thus, at the end of cycle III, Nostoc biomass in the system with copper contained 53.1\% less phycobiliproteins than in the control biomass. This system produced biomass with a low content of phycobiliproteins, although in cycle II there was a tendency to improve the consistency of this parameter. In contrast, in the third cycle of cultivation, the amount of phycobiliproteins again showed a significant decrease in comparison with both the control and the second cycle. The most interesting situation was observed in the $\mathrm{Cr} / \mathrm{Fe} / \mathrm{Ni} / \mathrm{Zn}$ system, where at the end of first cycle the lowest content of phycobiliproteins in Nostoc biomass was recorded (with a reduction of over $60 \%$ compared with control). Then, in the second cycle, an increase in this parameter compared with cycle I was noticed, but it was not able to reach the control values and remained $17.3 \%$ lower compared with the control. In the third cycle, phycobiliprotein pigments almost doubled their content in biomass in comparison with the second cycle. This was the maximum value of the parameter within the experiment $(46.3 \%$ more than in the control sample).

The amount of chlorophyll in Nostoc biomass during cycles I and II was at the control level in $\mathrm{Cr} / \mathrm{Fe}, \mathrm{Cr} / \mathrm{Fe} / \mathrm{Ni}$, and $\mathrm{Cr} / \mathrm{Fe} / \mathrm{Ni} / \mathrm{Zn} / \mathrm{Cu}$ systems. However, in the $\mathrm{Cr} / \mathrm{Fe} / \mathrm{Ni} / \mathrm{Zn}$ system, it was $33.3 \%$ and $47.8 \%$, respectively, higher than in the control $(p<0.005)$. At the end of the third cultivation cycle, the amount of chlorophyll in the biomass obtained in $\mathrm{Cr} / \mathrm{Fe}, \mathrm{Cr} / \mathrm{Fe} / \mathrm{Ni}$, and $\mathrm{Cr} / \mathrm{Fe} / \mathrm{Ni} / \mathrm{Zn}$ systems was $1.7-2.0$ times higher than in the control 
biomass. Only in one $\mathrm{Cr} / \mathrm{Fe} / \mathrm{Ni} / \mathrm{Zn} / \mathrm{Cu}$ system did the chlorophyll content in Nostoc biomass not change during three cultivation cycles compared with control.

For $\beta$-carotene, the same pattern was observed. In $\mathrm{Cr} / \mathrm{Fe}$ and $\mathrm{Cr} / \mathrm{Fe} / \mathrm{Ni}$ systems, carotene content in the biomass in the first two cultivation cycles as well as in the $\mathrm{Cr} / \mathrm{Fe} / \mathrm{Ni} / \mathrm{Zn}$ system in the first cycle was at the level of control. The biomass in cycle II in the system containing copper contained $21.8 \%$ more $\beta$-carotene in comparison with the control $(p<0.01)$. In the third cycle of Nostoc growth, an increase in the amount of $\beta$-carotene in the three studied systems $\mathrm{Cr} / \mathrm{Fe}, \mathrm{Cr} / \mathrm{Fe} / \mathrm{Ni}$, and $\mathrm{Cr} / \mathrm{Fe} / \mathrm{Ni} / \mathrm{Zn}$ by $15.4 \%, 33.5 \%$, and $58.5 \%$, respectively, compared with control took place. In the $\mathrm{Cr} / \mathrm{Fe} / \mathrm{Ni} / \mathrm{Zn} / \mathrm{Cu}$ system, a decrease in the content of $\beta$-carotene by $14.5 \%$ and $26.3 \%$, respectively, in cycles II and III $(p<0.005)$ was noticed.

\subsection{The Antioxidant Activity of Nostoc Biomass}

The antioxidant activity of Nostoc biomass obtained in various multi-metallic systems has also changed (Figure 5). The antioxidant activity of aqueous extracts from Nostoc biomass grown in $\mathrm{Cr} / \mathrm{Fe}$ and $\mathrm{Cr} / \mathrm{Fe} / \mathrm{Ni}$ systems was lower than in the control in all three cultivation cycles (Figure 5). In $\mathrm{Cr} / \mathrm{Fe}$ system, a significant decrease in antioxidant activity was noted. In cycles I and II, the capacity to reduce $\mathrm{ABTS}^{\bullet+}$ radical cation was lower than in the control by $50.5 \%$ and $53.9 \%$, respectively, and in the cycle III - by $19.7 \%(p<0.005)$. The biomass obtained in the first cycle in the $\mathrm{Cr} / \mathrm{Fe} / \mathrm{Ni}$ system exhibited an antioxidant activity (water extract) $36.4 \%$ lower than the control. In the next two cycles, this parameter increased but did not reach the control level. In $\mathrm{Cr} / \mathrm{Fe} / \mathrm{Ni} / \mathrm{Zn}$ system, the biomass after the first two cycles had the antioxidant activity of water-soluble components of about $33 \%$ lower compared with the control, while the antioxidant activity of biomass after the third cycle was equal to the control biomass. The $\mathrm{Cr} / \mathrm{Fe} / \mathrm{Ni} / \mathrm{Zn} / \mathrm{Cu}$ system in first and third cycles produced Nostoc biomass, whose activity of water-soluble components was $16.6 \%$ and $46.8 \%$, respectively, lower than in the control, and in the second cycle the value of this parameter was at the level of the control.
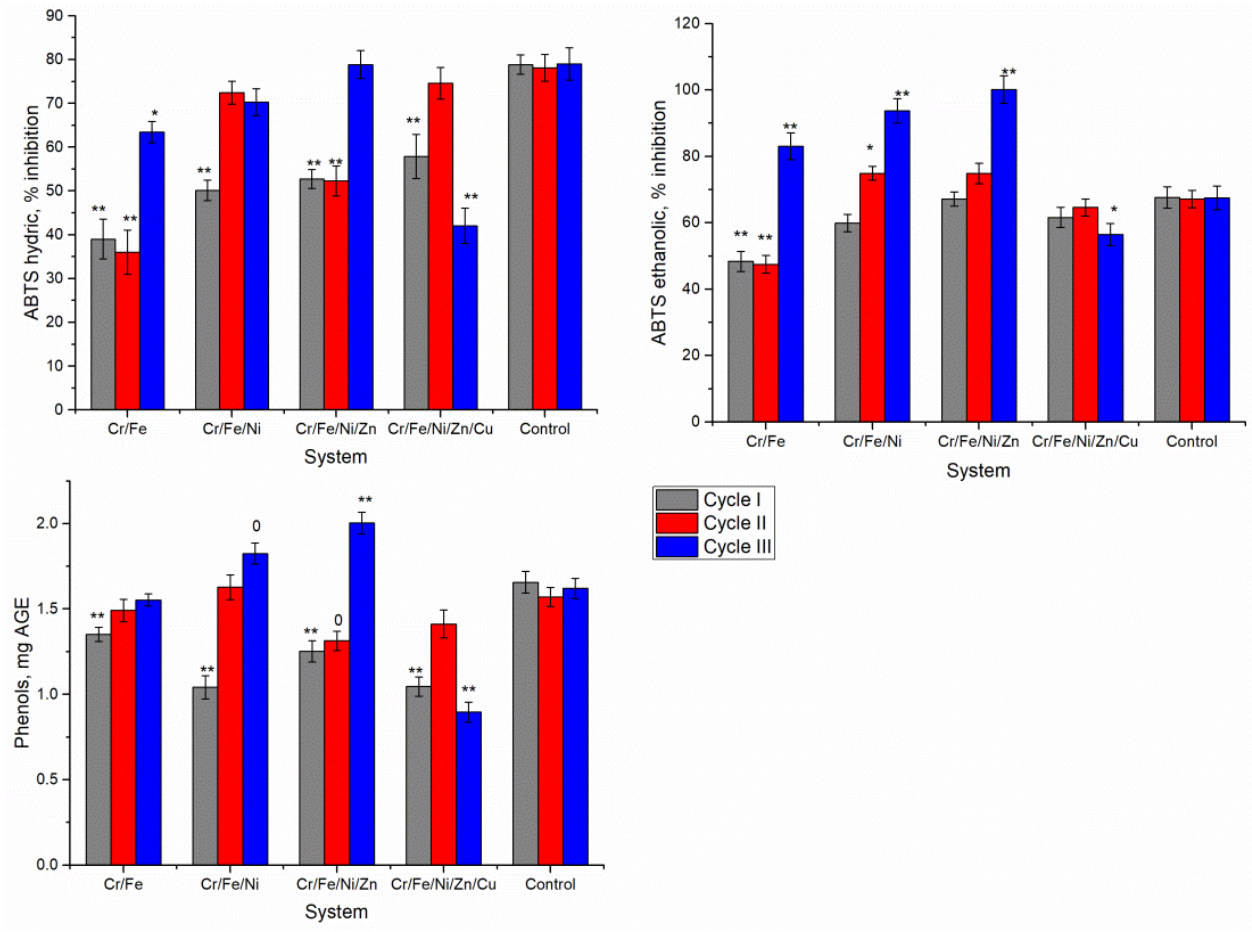

ystem

Figure 5. Antioxidant activity $\left(\%\right.$ inhibition of $\mathrm{ABTS}^{\bullet+}$ ) of water and ethanolic extracts; and phenolic content in Nostoc linckia biomass during three cycles of cultivation on media containing multi-metallic systems. $\left({ }^{\circ} p<0.01 ;{ }^{*} p<0.005 ;{ }^{* *} p<0.001\right)$. 
The antioxidant activity of ethanol extracts from Nostoc biomass also changed depending on the system and the cultivation cycle (Figure 5). Both decrease and increase in this parameter were observed. In the $\mathrm{Cr} / \mathrm{Fe}$ system, a decrease in antioxidant activity was observed in the first two cycles (by about 30\%, $p<0.001$ ). The highest increase in antioxidant activity by $22.9-48.2 \%$ in comparison with the control was obtained for Nostoc biomass in the third cultivation cycle, in three analyzed systems $\mathrm{Cr} / \mathrm{Fe}, \mathrm{Cr} / \mathrm{Fe} / \mathrm{Ni}$, and $\mathrm{Cr} / \mathrm{Fe} / \mathrm{Ni} / \mathrm{Zn}$. In the $\mathrm{Cr} / \mathrm{Fe} / \mathrm{Ni} / \mathrm{Zn} / \mathrm{Cu}$ system, the decrease in antioxidant activity of ethanol extracts with respect to control was noticed.

The content of phenolic compounds in Nostoc biomass, which largely exhibit antioxidant activity, also changed in the presence of heavy metals in the systems (Figure 5). The amount of phenols in the biomass of the first cycle, regardless of the system, decreased by 18.5-24.4\% compared with the control $(p<0.001)$. In the second cycle, with the exception of the $\mathrm{Cr} / \mathrm{Fe} / \mathrm{Ni} / \mathrm{Zn}$ system, where there was a slight decrease in the content of phenolic compounds (by $16.4 \%, p<0.01$ ), the values of this parameter in other systems were almost on the level of control biomass. In cycle III, biomass grown in $\mathrm{Cr} / \mathrm{Fe}$ and $\mathrm{Cr} / \mathrm{Fe} / \mathrm{Ni}$ systems contained an amount of phenols very close to that in the control, while in the $\mathrm{Cr} / \mathrm{Fe} / \mathrm{Ni} / \mathrm{Zn}$ system this parameter was $23.6 \%$ higher than in the control $(p<0.001)$, and in the $\mathrm{Cr} / \mathrm{Fe} / \mathrm{Ni} / \mathrm{Zn} / \mathrm{Cu}$ system it was $44.7 \%$ lower than in the control $(p<0.001)$.

\section{Discussion}

The main objective of this study was to assess the ability of cyanobacterium Nostoc linkia to accumulate $\mathrm{Cr}(\mathrm{VI})$ along with other metal ions during three successive cultivation cycles.

Currently, the ability of various bacterial species to accumulate $\mathrm{Cr}(\mathrm{VI})$ is being intensively studied. It is known that bacteria, Bacillus pumilus, Bacillus circulans, Bacillus megaterium, Bacillus sphaericus, Exiguobacterium aurantiacum, Pseudomonas synxantha, and Pseudomonas brenneri, depending on the experimental conditions, accumulate from $23 \%$ to $90 \%$ of $\mathrm{Cr}(\mathrm{VI})$ present in the medium [24-27].

Cyanobacteria Chroococcus sp., Limnococcus sp., Limnococcus ceylanica, and Gleocapsa sp. also possess a very high bioaccumulation efficiency toward metal ions [28-30]. Several species Limnococcus sp., Nostoc muscorum, and Synechococcus sp. have been appreciated for their ability of high and rapid bioaccumulation of heavy metals, others, such as Synechococcus sp.--for the ability to accumulate a wide variety of metals.

Among cyanobacteria of the genus Nostoc, the most studied in this regard is Nostoc muscorum [31,32], while there are few research papers devoted to Nostoc linckia. It is rather important to obtain new knowledge about the ability of cyanobacterium $N$. linckia to accumulate metals, including $\mathrm{Cr}(\mathrm{VI})$.

In present research, the bioaccumulation of $\mathrm{Cr}(\mathrm{VI})$ from multi-metallic systems was studied-a situation that is closer to real conditions, since in most cases the contamination of certain areas occurs due to the presence of several pollutants. Among the four studied systems, in $\mathrm{Cr} / \mathrm{Fe}, \mathrm{Cr} / \mathrm{Fe} / \mathrm{Ni}$, and $\mathrm{Cr} / \mathrm{Fe} / \mathrm{Ni} / \mathrm{Zn} / \mathrm{Cu}$, the rate of chromium uptake by Nostoc was very similar and varied with the cultivation cycle. Thus, in these three systems, chromium recovery in the first cycle was 35.8-40.2\% of the initial level of metal; in the second cycle-27.2-32.7\%, and in the third cycle-19.7-27.1\%. In the $\mathrm{Cr} / \mathrm{Fe} / \mathrm{Ni} / \mathrm{Zn}$ system, the bioaccumulation capacity of Nostoc biomass was significantly higher and amounted to $63.1 \%, 56.0 \%$, and $34.8 \%$ of $\mathrm{Cr}(\mathrm{VI})$, which corresponds to three cultivation cycles.

It was shown that the uptake of chromium by Nostoc biomass can reach values that are 1000 times higher than the normal level of this element in biomass. Comparing the ability of spirulina and Nostoc to accumulate $\mathrm{Cr}(\mathrm{VI})$ under similar conditions it can be seen that spirulina accumulate 20 times less metal compared with Nostoc-from 62 to $182 \mu \mathrm{g} / \mathrm{g}$ biomass [18].

As a minor element for cyanobacterium, chromium was most likely absorbed through nonspecific mechanisms, and the ability to excessively accumulate this metal is an obvious feature of this strain. The peculiarity observed in this experiment was that the metal content relative to biomass was higher in the second cultivation cycle, regardless of the system. 
However, the bioaccumulation capacity of biomass in the second cycle was lower due to a decrease in the amount of produced biomass. It can be assumed that Nostoc culture, which has not been previously exposed to the toxic effects of heavy metals (the first cultivation cycle), has a higher degree of resistance to the action of exogenous stress, while repeated stress (in the second and third cycles) leads to a significant diminution of resistance. As a result, cell proliferation was limited, which led to a decrease in productivity and biomass accumulation.

Iron, $\mathrm{Ni}, \mathrm{Zn}$, and $\mathrm{Cu}$ in the studied systems were taken up during the cultivation of Nostoc biomass over the cycles. For instance, iron uptake from the solution in the first cycle was 59-78\% and it was accumulated almost completely in the next two cycles. Nickel uptake constituted $43.2-62.6 \%$ in the first cycle and $49.7-83.1 \%$ in the next two cycles, being in ascent from one cycle to the next in all systems containing this element.

Zinc was present in two systems: $\mathrm{Cr} / \mathrm{Fe} / \mathrm{Ni} / \mathrm{Zn}$ and $\mathrm{Cr} / \mathrm{Fe} / \mathrm{Ni} / \mathrm{Zn} / \mathrm{Cu}$. In the first system, the percentage of metal recovery by Nostoc biomass was at the same level in three cycles and amounted to 37.1-39.8\% of the initial zinc content. In the $\mathrm{Cr} / \mathrm{Fe} / \mathrm{Zn} / \mathrm{Ni} / \mathrm{Cu}$ system, zinc uptake increased from $25.8 \%$ in the first cycle to $54.5 \%$ in the third. Copper uptake was $46.5-57.8 \%$, and its maximum amount was accumulated in the second cycle of Nostoc cultivation.

Thus, Nostoc linkia can be considered as a good accumulator of chromium as well as other metals in multi-metallic systems. The resistance of cyanobacterium to these metals was also confirmed by the quality of biomass, which at the first cycle of cultivation in the presence of metals did not change or changed insignificantly. This allows us to appreciate the protection systems of Nostoc linkia as effective.

The repeated contact of cyanobacterium with pollutants induced several changes in Nostoc biomass, which most likely aimed at diminishing the negative effects of heavy metals, especially $\mathrm{Cr}(\mathrm{VI})$. In particular, in the third cycle, there was a significant increase in the antioxidant activity of the ethanol-soluble components, $\beta$-carotene, chlorophyll, and phycobiliproteins in $\mathrm{Cr} / \mathrm{Fe}, \mathrm{Cr} / \mathrm{Fe} / \mathrm{Ni}$, and $\mathrm{Cr} / \mathrm{Fe} / \mathrm{Ni} / \mathrm{Zn}$ systems. A significant presence of antioxidant components can annihilate the harmful action of reactive oxygen species, which can be generated as a result of the interaction of heavy metals with Nostoc cells. Pigments, in addition to having direct antioxidant activity, absorb the light energy needed for photosynthesis. As a result, in systems where Nostoc biomass had an increased level of pigments, the amount of lipids, carbohydrates, and proteins was at an adequate level. The increase in the amount of chlorophyll and its derivatives, carotene and phycobiliproteins, in the biomass of cyanobacteria and microalgae exposed to stress caused by the presence of chromium, as well as other metals, was observed by other researchers, and is in line with our results $[29,33]$.

However, it was obvious that the described changes cannot completely remove the negative effects of heavy metals. Thus, a reduced amount of biomass in cycles II and III and an increase in the amount of malondialdehyde, a recognized marker of oxidative stress, denoted a moderate level of stress, but did not seriously affect the quality of Nostoc biomass.

Nostoc linckia is a filamentous nitrogen-fixing cyanobacterium which populates both water and soil. In soil, different species of Nostoc can be a part of the biological soil crust, or they can be free-living [34,35]. The live cyanobacterial cells are used as a simple, low-cost and efficient bio-fertilizer that can improve the physicochemical properties of the soil by enriching it with carbon, nitrogen, and available phosphorus [36].

Based on the foregoing, there are two ways in which Nostoc biomass can be used for soil bioremediation: introduction of culture in soil by spraying and application of Nostoc culture immobilized on a neutral carrier. In the first case, it is necessary to ensure humidity for the development of the Nostoc colonies, which will ensure the remediation of the soil at the surface and at a depth of 1-5 cm. In conditions of low humidity, Nostoc forms easily removable crusts, which can be collected or, when they remain on the ground with an increase in humidity their vital activity resumes (which corresponds to cycle II and III of the experiment). In the second case, the technology of the use of immobilized microorganisms in soil conditions can be applied. It is obvious that for application in practice, additional 
research is required, and remediation technologies will be applicable for bioremediation of limited sites. Nevertheless, the high bioaccumulation capacity toward metal ions, as well as the specific growth with surface crust formation and the resistance to drought make this cyanobacterium an important candidate for the development of bioremediation technologies of soils contaminated with heavy metals, especially $\mathrm{Cr}(\mathrm{VI})$.

\section{Conclusions}

The culture of Nostoc linckia, which was not previously subjected to heavy metal stress, has demonstrated resistance to polymetallic systems and a high bioaccumulation capacity for $\mathrm{Cr}(\mathrm{VI})$ and other metal ions.

The ability to bioaccumulate $\mathrm{Cr}(\mathrm{VI})$ from the contaminated medium by cyanobacterium Nostoc linckia still remained high over three generations, while the uptake of Fe, $\mathrm{Ni}$, $\mathrm{Cu}$, and $\mathrm{Zn}$ in biomass increased from generation to generation.

The repeated action of metals led to a state of moderate stress, expressed in a decrease in the amount of biomass and the accumulation of malondialdehyde. At the same time, the quality of biomass remained unaltered.

Maintaining the quality of Nostoc biomass under stress conditions caused by the presence of metals is ensured by an increase in the content of compounds with antioxidant action.

Due to its high bioaccumulation capacity and a specific growth pattern with the formation of crusts on soil surface, edaphic cyanobacterium Nostoc linckia is an important candidate for bioremediation of soil contaminated with $\mathrm{Cr}$ in combination with other metals. In this regard, further research in real soil conditions is necessary.

Author Contributions: Conceptualization, L.C. (Liliana Cepoi) and I.Z.; methodology, L.C. (Liliana Cepoi), A.V., L.C. (Liviu Codreanu), L.R. and T.C.; software, I.Z.; validation, L.C. (Liliana Cepoi), I.Z., L.R. and A.V.; formal analysis, A.V., L.C. (Liviu Codreanu), and T.C.; samples irradiation, D.G. and N.Y.; spectra processing A.P.; writing-original draft preparation, L.C. (Liliana Cepoi), and I.Z.; writing-review and editing, L.C. (Liliana Cepoi), I.Z., T.C., L.R., A.V. and L.C. (Liviu Codreanu); visualization, I.Z. All authors have read and agreed to the published version of the manuscript.

Funding: This research received no external funding.

Institutional Review Board Statement: Not applicable.

Informed Consent Statement: Not applicable.

Conflicts of Interest: The authors declare no conflict of interest.

\section{References}

1. Tumolo, M.; Ancona, V.; De Paola, D.; Losacco, D.; Campanale, C.; Massarelli, C.; Uricchio, V.F. Chromium pollution in European water, sources, health risk, and remediation strategies: An overview. Int. J. Environ. Res. Public Health 2020, 17, 5438. [CrossRef]

2. Xia, S.; Song, Z.; Jeyakumar, P.; Shaheen, S.M.; Rinklebe, J.; Ok, Y.S.; Bolan, N.; Wang, H. A critical review on bioremediation technologies for Cr(VI)-contaminated soils and wastewater. Crit. Rev. Environ. Sci. Technol. 2019, 49, 1027-1078. [CrossRef]

3. Wang, Y.; Su, H.; Gu, Y.; Song, X.; Zhao, J. Carcinogenicity of chromium and chemoprevention: A brief update. Onco. Targets. Ther. 2017, 10, 4065-4079. [CrossRef] [PubMed]

4. Ashraf, A.; Bibi, I.; Niazi, N.K.; Ok, Y.S.; Murtaza, G.; Shahid, M.; Kunhikrishnan, A.; Li, D.; Mahmood, T. Chromium(VI) sorption efficiency of acid-activated banana peel over organo-montmorillonite in aqueous solutions. Int. J. Phytoremediation 2017, 19, 605-613. [CrossRef] [PubMed]

5. Ertani, A.; Mietto, A.; Borin, M.; Nardi, S. Chromium in Agricultural Soils and Crops: A Review. Water Air Soil Pollut. 2017, 228, 190. [CrossRef]

6. Guo, S.; Xiao, C.; Zhou, N.; Chi, R. Speciation, toxicity, microbial remediation and phytoremediation of soil chromium contamination. Environ. Chem. Lett. 2021, 9, 1413-1431. [CrossRef]

7. Antonkiewicz, J.; Pełka, R.; Bik-Małodzińska, M.; Żukowska, G.; Gleń-Karolczyk, K. The effect of cellulose production waste and municipal sewage sludge on biomass and heavy metal uptake by a plant mixture. Environ. Sci. Pollut. Res. 2018, 25, 31101-31112. [CrossRef]

8. Wang, C.; Deng, H.; Zhao, F. The Remediation of Chromium (VI)-Contaminated Soils Using Microbial Fuel Cells. Soil Sediment Contam. 2016, 25, 1-12. [CrossRef]

9. Wang, Y.; Yang, Z.; Peng, B.; Chai, L.; Wu, B.; Wu, R. Biotreatment of chromite ore processing residue by Pannonibacter phragmitetus BB. Environ. Sci. Pollut. Res. 2013, 20, 5593-5602. [CrossRef] [PubMed] 
10. Tekerlekopoulou, A.G.; Tsiflikiotou, M.; Akritidou, L.; Viennas, A.; Tsiamis, G.; Pavlou, S.; Bourtzis, K.; Vayenas, D.V. Modelling of biological $\mathrm{Cr}(\mathrm{VI})$ removal in draw-fill reactors using microorganisms in suspended and attached growth systems. Water Res. 2013, 47, 623-636. [CrossRef]

11. Fernández, P.M.; Viñarta, S.C.; Bernal, A.R.; Cruz, E.L.; Figueroa, L.I.C. Bioremediation strategies for chromium removal: Current research, scale-up approach and future perspectives. Chemosphere 2018, 208, 139-148. [CrossRef]

12. Cheung, K.H.; Gu, J.D. Mechanism of hexavalent chromium detoxification by microorganisms and bioremediation application potential: A review. Int. Biodeterior. Biodegrad. 2007, 59, 8-15. [CrossRef]

13. Zinicovscaia, I.; Cepoi, L.; Valuţă, A.; Rudi, L.; Culicov, O.A.; Frontasyeva, M.; Kirkesali, E.; Pavlov, S.; Mitina, T. Nostoc Linckia as Biosorbent of Chromium and Nickel from Electroplating Industry Wastewaters. J. Mater. Sci. Eng. B 2014, 4, 242-247. [CrossRef]

14. Zinicovscaia, I.; Safonov, A.; Tregubova, V.; Ilin, V.; Cepoi, L.; Chiriac, T.; Rudi, L.; Frontasyeva, M.V. Uptake of metals from single and multi-component systems by spirulina platensis biomass. Ecol. Chem. Eng. S 2016, 23, 401-412. [CrossRef]

15. Frontasyeva, M.V. Neutron activation analysis in the life sciences. Phys. Part. Nucl. 2011, 42, 332-378. [CrossRef]

16. Pavlov, S.S.; Dmitriev, A.Y.; Frontasyeva, M.V. Automation system for neutron activation analysis at the reactor IBR-2, Frank Laboratory of Neutron Physics, Joint Institute for Nuclear Research, Dubna, Russia. J. Radioanal. Nucl. Chem. 2016, 309 , 27-38. [CrossRef] [PubMed]

17. Lowry, O.H.; Rosebrough, N.J.; Farr, A.L.; Randall, R.J. Protein measurement with the Folin phenol reagent. J. Biol. Chem. 1951, 193, 265-275. [CrossRef]

18. Cepoi, L.; Zinicovscaia, I.; Rudi, L.; Chiriac, T.; Rotari, I.; Turchenko, V.; Djur, S. Effects of PEG-coated silver and gold nanoparticles on spirulina platensis biomass during its growth in a closed system. Coatings 2020, 10, 717. [CrossRef]

19. Park, J.; Jeong, H.J.; Yoon, E.Y.; Moon, S.J. Easy and rapid quantification of lipid contents of marine dinoflagellates using the sulpho-phospho-vanillin method. Algae 2016, 31, 391-401. [CrossRef]

20. Singleton, V.L.; Rossi, J.A. Colorimetry of total phenolics with phosphomolybdic-phosphotungstic acid reagents. Am. J. Enol. Vitic. 1965, 16, 144-158.

21. Siegelman, H.; Kycia, J. Algal bili-proteins. In Handbook of Phycological Method; Hellebust, J., Craigie, J., Eds.; Cambridge University Press: Cambridge, UK, 1978; pp. 71-79.

22. Hodges, D.M.; DeLong, J.M.; Forney, C.F.; Prange, R.K. Improving the thiobarbituric acid-reactive-substances assay for estimating lipid peroxidation in plant tissues containing anthocyanin and other interfering compounds. Planta 1999, 207, 604-611. [CrossRef]

23. Re, R.; Pellegrini, N.; Proteggente, A.; Pannala, A.; Yang, M.; Rice-Evans, C. Antioxidant activity applying an improved ABTS radical cation decolorization assay. Free Radic. Biol. Med. 1999, 26, 1231-1237. [CrossRef]

24. Pattanapipitpaisal, P.; Mabbett, A.N.; Finlay, J.A.; Beswick, A.J.; Paterson-Beedle, M.; Essa, A.; Wright, J.; Tolley, M.R.; Badar, U.; Ahmed, N.; et al. Reduction of cr(vi) and bioaccumulation of chromium by gram positive and gram negative microorganisms not previously exposed to cr-stress. Environ. Technol. 2002, 23, 731-745. [CrossRef] [PubMed]

25. Srinath, T.; Verma, T.; Ramteke, P.W.; Garg, S.K. Chromium (VI) biosorption and bioaccumulation by chromate resistant bacteria. Chemosphere 2002, 48, 427-435. [CrossRef]

26. Velásquez, L.; Dussan, J. Biosorption and bioaccumulation of heavy metals on dead and living biomass of Bacillus sphaericus. J. Hazard. Mater. 2009, 167, 713-716. [CrossRef] [PubMed]

27. Banerjee, S.; Kamila, B.; Barman, S.; Joshi, S.R.; Mandal, T.; Halder, G. Interlining Cr(VI) remediation mechanism by a novel bacterium Pseudomonas brenneri isolated from coalmine wastewater. J. Environ. Manage. 2019, 233, 271-282. [CrossRef]

28. Kumar, M.S.; Praveenkumar, R.; Ilavarasi, A.; Rajeshwari, K.; Thajuddin, N. Oxidative stress response and fatty acid changes associated with bioaccumulation of chromium $[\mathrm{Cr}(\mathrm{VI})]$ by a fresh water cyanobacterium Chroococcus sp. Biotechnol. Lett. 2012, 34, 247-251. [CrossRef] [PubMed]

29. Kiran, B.; Kaushik, A.; Kaushik, C.P. Metal-salt co-tolerance and metal removal by indigenous cyanobacterial strains. Process Biochem. 2008, 43, 598-604. [CrossRef]

30. Al-Amin, A.; Parvin, F.; Chakraborty, J.; Kim, Y.I. Cyanobacteria mediated heavy metal removal: A review on mechanism, biosynthesis, and removal capability. Environ. Technol. Rev. 2021, 10, 44-57. [CrossRef]

31. Gupta, V.K.; Rastogi, A. Sorption and desorption studies of chromium(VI) from nonviable cyanobacterium Nostoc muscorum biomass. J. Hazard. Mater. 2008, 154, 347-354. [CrossRef]

32. Dixit, S.; Singh, D.P. Phycoremediation of lead and cadmium by employing Nostoc muscorum as biosorbent and optimization of its biosorption potential. Int. J. Phytoremediation 2013, 15, 801-813. [CrossRef] [PubMed]

33. Hörcsik, Z.; Oláh, V.; Balogh, Á.; Mészáros, I.; Simon, L.; Lakatos, G. Effect of chromium (VI) on growth, element and photosynthetic pigment composition of Chlorella pyrenoidosa. Acta Biol. Szeged. 2006, 50, 19-23.

34. Vinoth, M.; Sivasankari, S.; Ahamed, A.K.K.; Al-Arjani, A.-B.F.; Abd_Allah, E.F.; Baskar, K. Biological soil crust (BSC) is an effective biofertilizer on Vigna mungo (L.). Saudi J. Biol. Sci. 2020, 27, 2325-2332. [CrossRef]

35. Obana, S.; Miyamoto, K.; Morita, S.; Ohmori, M.; Inubushi, K. Effect of Nostoc sp. on soil characteristics, plant growth and nutrient uptake. J. Appl. Phycol. 2007, 19, 641-646. [CrossRef]

36. Singh, J.S.; Kumar, A.; Singh, M. Cyanobacteria: A sustainable and commercial bioresource in production of bio-fertilizer and bio-fuel from waste waters. Environ. Sustain. Indic. 2019, 3, 100008. [CrossRef] 